\title{
A comparative study of different preservation methods for phytoplankton cell analysis by flow cytometry
}

\author{
M. Lepesteur, J. M. Martin, A. Fleury \\ Institut de Biogéochimie marine, Unité de Recherche Associée au CNRS n 386 , Ecole Normale Supérieure, \\ 1, rue Maurice Arnoux, F-92120 Montrouge, France
}

\begin{abstract}
Ten methods to preserve phytoplankton populations for flow cytometric analyses were tested. These methods were differentiated by the rate of freezing and thawing, and the use or non-use of cryoprotectants (DMSO and/or glycerol) and chemical fixation. After freezing, the samples were stored in liquid nitrogen. These methods were tested on 3 freshwater and marine algal species. Different intensity parameters and 2 properties were considered. Firstly the number of cells lost, which was more significant with rapid freezing and chemical fixation, and less significant with the addition of cryoprotectants. Secondly, the preservation of both light scattering and fluorescence, which was better with slow freezing than with cryoprotectants. Slow freezing followed by chemical fixation appeared to be the best protocol studied and even if glycerol addition without chemical fixation seemed to be overall the best method, implying the use of cryoprotectant, all these techniques had to be tested on a case by case basis, particularly when phycocyanin and chlorophyll fluorescence were studied.
\end{abstract}

\section{INTRODUCTION}

Flow cytometry can simultaneously measure several parameters per cell: low angle light scattering $\left(<5^{\circ}\right)$, wide angle light scattering $\left(>15^{\circ}\right)$ and natural fluoresCence, with a light scatter sensitivity for particle sizes ranging from 0.2 to $180 \mu \mathrm{m}$. Commercial flow cytometers permit the analysis of 10000 cells $\mathrm{s}^{-1}$. This technique can measure more representative samples than epifluorescence microscopy. Additionally, after the staining of particles with specific fluorochromes, it is possible to differentiate living from non-living and organic from non-organic particles as a function of particle size, providing more useful information than conventional methods such as the coulter counter (Yentsch et al. 1983).

Flow cytometry has been applied successfully to the study of aquatic environments: plankton ecology (Yentsch et al. 1983, Burkill 1987. Cucci et al. 1989), organic coating components (Martin \& Moreira-Turcq 1991), and ecotoxicology (Premazzi et al. 1989). Most of these studies have been conducted either in the laboratory with in vitro cultures or aboard major research vessels during oceanographic cruises (Olson et al. 1985, Li 1989). But inherent difficulties are associated with the transport, installation and maintenance of flow cytometers onboard research vessels. Also, several methods have been already developed to preserve samples for subsequent analysis in the laboratory, e.g. ethanol or paraffin (Alanen et al. 1989a), citric acid buffered saline and ethanol (Alanen et al. 1989b) for DNA analysis in animal cells or rapid freezing in liquid nitrogen for phytoplankton (Vaulot \& Ning 1988). McGann et al. (1988) studied sample behavior after osmotic and freezing-thawing stress. For phytoplankton cells, Vaulot et al. (1989) recommend immediate fixation with $1 \%$ glutaraldehyde followed by storage in liquid nitrogen. This method has been proven to be suitable for cyanobacteria and small cells but presents many drawbacks such as cell loss and chlorophyll fluorescence variation for larger cells.

The main physical problem linked to preservation methods concerns the cellular damage caused by intracellular freezing. The amount of damage depends upon the freezing rate: At ultra-rapid freezing rate, little or no freezable water leaves the cell and intra- 
cellular ice forms. At moderate freezing rate, only part of the freezable water leaves cells which are not sufficiently dehydrated to cause injury; at slow freezing rate, all freezable water leaves cells which may suffer severe dehydration injuries. One possibility for avoiding internal freezing would be the addition of cryoprotectant just above the freezing temperature prior to chemical fixation, before supercooling (Withers 1985). Indeed, cryoprotectants have colligative properties, and maintain water in the liquid state by forming hydrogen bonds, preventing the diffusion of water molecules to the ice front and participating in the crystallization process (Finkle et al. 1985).

The aim of this study was to test the efficiency of cryoprotectants in preserving size, structure and pigment autofluorescence of different groups of phytoplankton cells to be further analyzed by flow cytometry.

\section{MATERIAL AND METHODS}

Cultures. Algal strains were obtained from algal collections (Laboratoire de Biologie Vegetale, Ecole Normale Supérieure, Paris, France): Synechocystis sp. (mean size $0.8 \mu \mathrm{m}$ ), a fresh water cyanobacteria and 2 marine species, Dunaliella sp. and Phaeodactylum tricornutum (mean size 3 and $30 \mu \mathrm{m}$ respectively). Duplicate batch cultures were maintained in growth at $18^{\circ} \mathrm{C}$ in specific medium at a light intensity of $100 \mu$ Ein $\mathrm{m}^{-2} \mathrm{~s}^{-1}$ and a 12L:12D cycle. Cells were sampled to test the preservation methods during the early stationary phase culture, except cyanobacteria, at a more advanced phase. Cyanobacteria were grown in BG11 (Rippka et al. 1979) medium (g 1 ${ }^{-1}$ ):

$\begin{array}{ll}\mathrm{MgSO}_{4} \cdot 7 \mathrm{H}_{2} \mathrm{O} & 0.075 \\ \mathrm{CaCl}_{2} \cdot 2 \mathrm{H}_{2} \mathrm{O} & 0.036 \\ \text { Citrate ferric ammonium } & 0.006 \\ \text { Citric acid } & 0.006 \\ \text { Magnesium tritiplex } & 0.001 \\ \mathrm{~K}_{2} \mathrm{HPO}_{4} \cdot 3 \mathrm{H}_{2} \mathrm{O} & 0.04 \\ \mathrm{NaNO}_{3} & 1.5 \\ \mathrm{Na}_{2} \mathrm{CO}_{3} & 0.04 \\ \mathrm{H}_{3} \mathrm{BO}_{3} & 0.0028 \\ \mathrm{MnCl}_{2} \cdot 4 \mathrm{H}_{2} \mathrm{O} & 0.00181 \\ \mathrm{ZnSO}_{4} \cdot 7 \mathrm{H}_{2} \mathrm{O} & 0.00022 \\ \mathrm{Na}_{2} \mathrm{MoO}_{4} \cdot 2 \mathrm{H} \mathrm{O} & 0.00039 \\ \mathrm{CuSO}_{4} \cdot 5 \mathrm{H}_{2} \mathrm{O} & 0.00008 \\ \mathrm{Co}\left(\mathrm{NO}_{3}\right)_{2} \cdot 6 \mathrm{H}_{2} \mathrm{O} & 0.00005\end{array}$

and Phaeodactylum tricornutum in $\mathrm{f} / 2$ medium (Guillard \& Ryther 1962). For Dunaliella sp., the growth medium (Berkaloff 1976) had the following composition $\left(\mathrm{g} \mathrm{l}^{-1}\right)$ :

$\begin{array}{ll}\mathrm{Cl}_{2} \mathrm{Cd} & 0.2 \\ \mathrm{KCl} & 1 \\ \mathrm{SO}_{4} \mathrm{Mg} \cdot 7 \mathrm{H}_{2} \mathrm{O} & 5 \\ \mathrm{NaCl} & 25 \\ \mathrm{NaNO}_{3} & 0.0025 \\ \mathrm{HNaPO}_{4} & 0.0004\end{array}$

$0.4 \mathrm{ml} \mathrm{A}$ medium $\left(\mathrm{mg} \mathrm{l}^{-1}\right)$ :

$\begin{array}{ll}\mathrm{H}_{3} \mathrm{BO}_{3} & 0.002852 \\ \mathrm{MnCl}_{4} \cdot 4 \mathrm{H}_{2} \mathrm{O} & 0.002690 \\ \mathrm{ZnSO} \cdot 7 \mathrm{H}_{2} \mathrm{O} & 0.000212 \\ \mathrm{CuSO}_{4} \cdot 5 \mathrm{H}_{2} \mathrm{O} & 0.000074 \\ \mathrm{MoO}_{3} & 0.000012 \\ \mathrm{H}_{2} \mathrm{SO}_{4} & 0.024500\end{array}$

$0.4 \mathrm{ml} \mathrm{B}_{6}$ medium $\left(\mathrm{mg} \mathrm{l}^{-1}\right)$ :

$\begin{array}{ll}\mathrm{NH}_{4} \mathrm{VO}_{3} & 0.000117 \\ \mathrm{~K}_{2} \mathrm{Cr}_{2}\left(\mathrm{SO}_{4}\right)_{3} \cdot 2 \mathrm{H}_{2} \mathrm{O} & 0.000404 \\ \mathrm{NiSO}_{4} \cdot 7 \mathrm{H}_{2} \mathrm{O} & 0.000238 \\ \mathrm{Co}\left(\mathrm{NO}_{3}\right)_{2} \cdot 6 \mathrm{H}_{2} \mathrm{O} & 0.000247 \\ \mathrm{Na}_{2} \mathrm{WO}_{4} \cdot 12 \mathrm{H}_{2} \mathrm{O} & 0.000153 \\ \mathrm{Ti}\left(\mathrm{SO}_{4}\right)_{3} & 0.000218,\end{array}$

and $1 \mathrm{l}$ filtered sea water. $\mathrm{pH}$ had to be adjusted to 7.7 with a $\mathrm{CO}_{3} \mathrm{Na}_{2}$ solution. All the media were sterilized by autoclaving except the vitamin solution of the $1 / 2$ medium which was sterilized by filtration.

Preservation methods. Aliquots of fresh samples $\left(1 \mathrm{ml}\right.$ with a concentration of $10^{6}$ cells $\mathrm{ml}^{-1}$ ) were transferred in $1.2 \mathrm{ml}$ cryotubes (Nalgene Company, New York, NY, USA), then subjected to different protocols (Table 1) followed by storage in liquid nitrogen for 1 wk or 1 mo before analysis.

Addition of cryoprotectants: Cryoprotectants were added drop by drop at about $4^{\circ} \mathrm{C}$ with constant agitation. The following sterile cryoprotectants were used: dimethylsulfoxide (DMSO) 10\%, glycerol $20 \%$ and a mixture of DMSO $10 \%$ and glycerol $10 \%$ v/v (Sigma, St. Louis, MO, USA). A mixture of cryoprotectants was used to reduce their individual toxicity by dilution, and to allow one cryoprotectant to enter the cell due to the other's permeabilization effect.

Chemical fixation: Fifteen minutes after addition of the cryoprotectants, glutaraldehyde $(\mathrm{pH} 7.51,1 \%$ final concentration) was added and incubated for a period of 10 min at room temperature.

Freezing: The response of cells to the stress of cooling depends on the phase of the culture. Cells from the exponential phase are the most sensitive and their sensitivity to cold shock appears to be proportional to the growth rate (Morris 1987). For this reason, all cells (except cyanobacteria) were treated during the early stationary phase of culture. For rapid freezing, samples were immersed immediately in liquid nitrogen without supercooling. For slow freezing, samples were supercooled at a rate of $3^{\circ} \mathrm{C} \mathrm{min}^{-1}$ until about $-40^{\circ} \mathrm{C}$, before 
Table 1 . Summary of the 10 protocols

\begin{tabular}{|rcccc|}
\hline $\begin{array}{c}\text { Protocol } \\
\text { no. }\end{array}$ & $\begin{array}{c}\text { Cryo- } \\
\text { protectants }\end{array}$ & $\begin{array}{c}\text { Chemical } \\
\text { fixation }\end{array}$ & Freezing & Thawing \\
\hline 1 & None & None & Rapid & Slow \\
2 & None & Glutaraldehyde & Rapid & Slow \\
3 & None & None & Slow & Rapid \\
4 & None & None & Slow & Rapid \\
5 & DMSO & None & Slow & Rapid \\
6 & Glycerol & None & Slow & Rapid \\
7 & DMSO+glycerol & Glutaraldehyde & Slow & Rapid \\
8 & DMSO & Glutaraldehyde & Slow & Rapid \\
9 & Glycerol & Glutaraldehyde & Slow & Rapid \\
10 & DMSO+glycerol & GMolde & &
\end{tabular}

1.02735 for an ideal amplifier, $L$ is the median, and $\sigma^{2}$ is the population variance (BrunCottan 1986). This rescaling into linear form allows a direct comparison of intensity differences (Schmidt et al. 1988).

\section{RESULTS AND DISCUSSION}

The Student's t-test was used to compare the means of the fresh and the treated samples (Table 2). Promising results for the FALS parameter were obtained with Protocols 4,8 and 10 for Dunaliella sp. For WALS, Protocols 2 and 5 were able to preserve the being plunged directly in liquid nitrogen. It was very difficult to predict an optimum rate of supercooling because of the variability of cellular permeability according to surface/volume ratio.

Thawing: Slow thawing occurred at room temperature. Rapid thawing was used for most cell suspensions. Ampules were retrieved from liquid nitrogen and plunged directly into a water bath at ca $38^{\circ} \mathrm{C}$. With constant agitation, thawing was complete in 1 or 2 min. Rapid thawing avoided any damage due to recrystallization.

Flow cytometry. All samples were analysed by flow cytometry with a Bruker ACR 1000 using a $488 \mathrm{~nm}$ excitation wavelength with a light source from a high pressure $100 \mathrm{~W}$ mercury arc. Sheath fluid was filtered through a $0.22 \mu \mathrm{m}$ pore size Nuclepore filter. A $100 \mu \mathrm{l}$ portion of each sample was injected into the cytometer. After cell counting, original fresh samples were diluted to a concentration of $10^{6}$ to $10^{7}$ cells $\mathrm{ml}^{-1}$. Calibration was achieved using $1.96 \mu \mathrm{m}$ fluorescent beads (Polysciences, Warrington, PA, USA). Results were stored in data mode. Each of the 4 parameters studied, forward angle light scattering (FALS), wide angle light scattering (WALS), chlorophyll fluorescence intensity (CHL) and phycocyanine fluorescence intensity (PHY), was recorded on a 3 decade logarithmic scale and mapped onto 256 channels. The 2 fluorescent components were isolated by passing through a $670-700 \mathrm{~nm}$ band pass absorbance filter for chl a fluorescence and a $630 \mathrm{~nm}$ short pass filter for phycocyanin fluorescence respectively.

Statistical analysis. The Student's t-test was performed with fresh and preserved samples (after storage of $1 \mathrm{wk}$ ) of each population. To measure diversity in the parameters, a ratio $R$ was computed as follows: $\mathrm{R}=\mu_{\mathrm{p}} / \mu_{\mathrm{F}}$, where $\mu$ is the linear mean of cryoprotected or chemical fixed (P) and initial (F) samples respectively, and $\mu=\beta^{\left(L+1 / 2 \sigma^{2}\right)}$, where $\beta=1000^{(1 / 256)}=$ log-normal mean, but only for Phaeodactylum tricornutum. CHL tolerated Protocol 6 for Dunaliella sp., and PHY, Protocols 4, 8 and 10. These protocols were chosen because their observed $\chi^{2}$ values were less than the theoretical $\chi^{2}$ values $(\alpha=0.5 \%)$. The Student's $t$-test indicated the chemical fixation efficiency for Synechocystis sp. PHY and Dunaliella sp. FALS.

Even if chemical fixation seemed to be better, particularly for Synechocystis sp., cell loss was significant with rapid freezing. Conversely, cell loss is less significant with the cryoprotectants, but pigment fluorescence intensities were not as well preserved. The Student's $t$ test was not sufficient to discover all the variations which could be observed in the treated samples.

$(R-1)$ was calculated to compare the variation of the preserved sample relative to the fresh sample (Fig. 1A to E). Phaeodactylum tricornutum showed the highest variation in cell concentration with Protocol 6 and the highest variation of FALS intensity with Protocol 3. But the maximum variations of WALS and CHL intensities of PHY intensity with Protocol 2.

The following sections discuss the global efficiency of each protocol. Two aspects are considered: first, intensity of light diffusion and pigment fluorescence of the preserved population compared to that of the fresh one, and second, preservation of cell concentration (Table 3).

Table 2. Best methods of preservation of different strains' parameters (Student's $t$-test). FALS: forward angle light scattering; WALS: wide angle light scattering; CHL: chlorophyll fluorescence intensity; PHY: phycocyanine fluorescence intensity

\begin{tabular}{|lrcc|}
\hline & Synechocystis sp. & Phaeodectylum tricornutum & Dunaliellasp. \\
\hline FALS & - & - & Protocols 4, 8, 10 \\
WALS & - & Protocols 2,5 & - \\
CHL & - & - & Protocol 6 \\
PHY & Protocols 4,8,10 & & \\
\hline
\end{tabular}
were observed for Dunaliella sp. with Protocol 7, and 
Synechocystis sp.
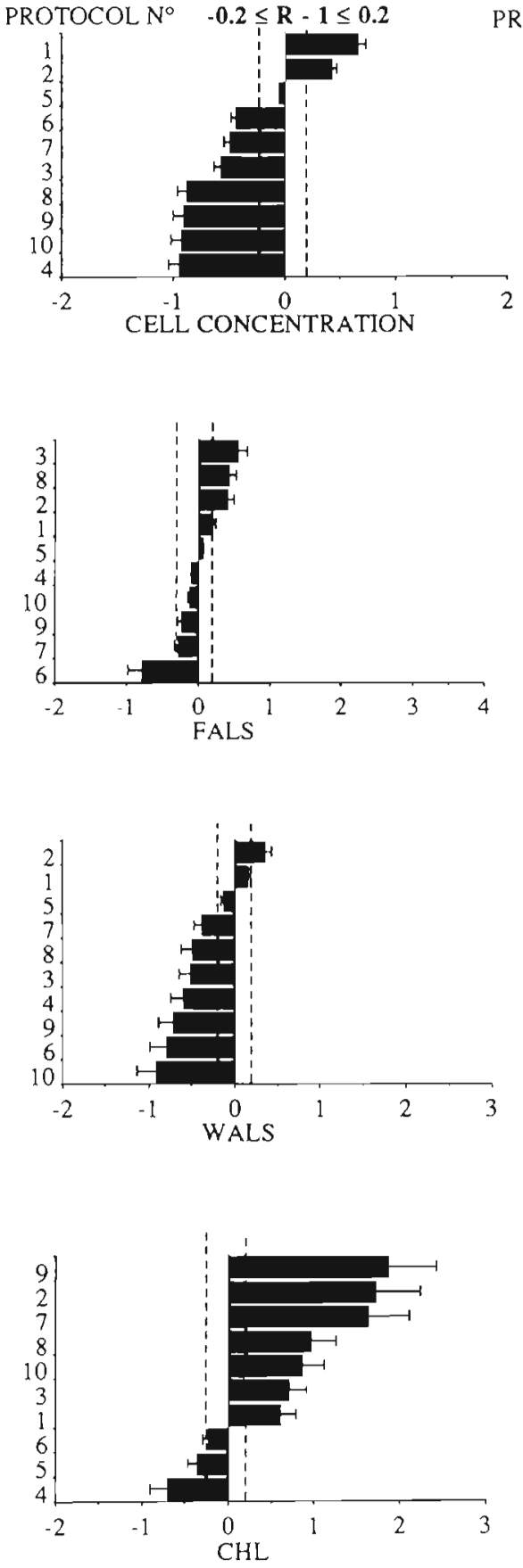

$\mathrm{E}$

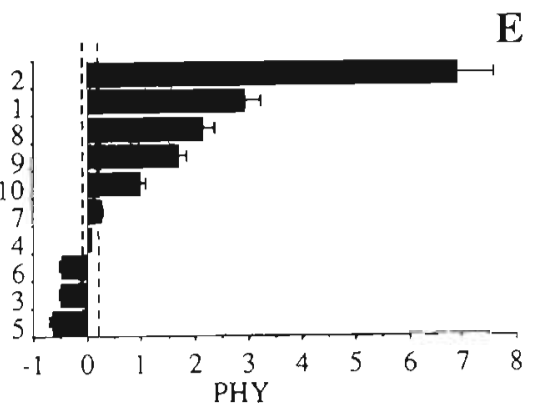

Phaeodactylum tricornutum

PROTOCOL N ${ }^{\circ}-0.2 \leq \mathbf{R}-1 \leq \mathbf{0 . 2}$
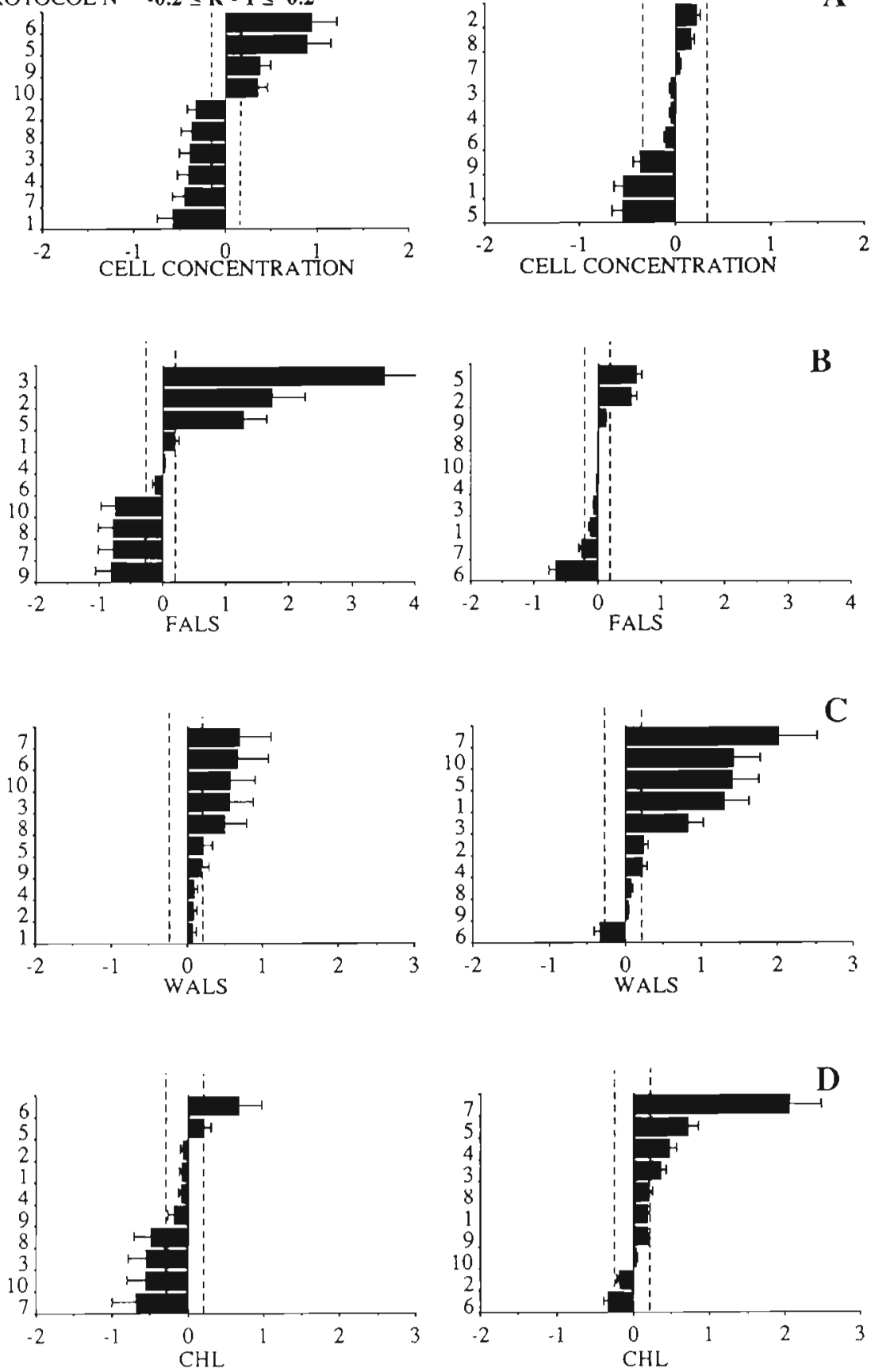

Fig. 1. Variation of $(R-1)$, where $R$ is the preserved/fresh ratio, for cell concentration (A), forward angle light scattering (FALS, B), wide angle light scattering (WALS, C), chlorophyll fluorescence $(\mathrm{CHL}, \mathrm{D})$ and phycocyanin fluorescence (PHY, E) with the different protocols applied to the fresh samples after $1 \mathrm{wk}$ of storage 
Table 3. Global efficiency of each protocol. Parameters as in Table 2. Syn.: Synechocystis sp.; Phae.: Phaeodactylum tricornutum; Dun.: Dunaliella sp.; +: variation $\leq 20 \% ; 0: 20 \%<$ variation $<80 \%$; $: \geq 80 \%$

\begin{tabular}{|c|c|c|c|c|c|c|c|c|c|c|}
\hline $\begin{array}{l}\text { Protocol } \\
\text { no. }\end{array}$ & Strain & FALS & WALS & $\mathrm{CHL}$ & PHY & $\begin{array}{c}\text { Total inten- } \\
\text { sities variation }\end{array}$ & $\begin{array}{l}\text { Cell } \\
\text { conc. }\end{array}$ & $\begin{array}{l}\text { Cell conc. } \\
\text { variation }\end{array}$ & $\begin{array}{l}\text { Total popula- } \\
\text { tion variation }\end{array}$ & Acceptance \\
\hline 1 & $\begin{array}{l}\text { Syn. } \\
\text { Phae. } \\
\text { Dun. }\end{array}$ & $\begin{array}{l}+ \\
+ \\
+\end{array}$ & $\begin{array}{l}+ \\
0 \\
-\end{array}$ & $\begin{array}{l}0 \\
+ \\
+\end{array}$ & - & $58.9 \%$ & $\begin{array}{l}- \\
0 \\
0\end{array}$ & $59 \%$ & $58.9 \%$ & No \\
\hline 2 & $\begin{array}{l}\text { Syn. } \\
\text { Phae. } \\
\text { Dun. }\end{array}$ & $\begin{array}{l}+ \\
0 \\
+\end{array}$ & $\begin{array}{l}0 \\
0 \\
0\end{array}$ & $\begin{array}{l}- \\
+ \\
+\end{array}$ & - & $122.9 \%$ & $\begin{array}{l}0 \\
0 \\
0\end{array}$ & $32.3 \%$ & $89 \%$ & No \\
\hline 3 & $\begin{array}{l}\text { Syn. } \\
\text { Phae. } \\
\text { Dun. }\end{array}$ & $\begin{array}{l}0 \\
- \\
+\end{array}$ & $\begin{array}{l}0 \\
- \\
-\end{array}$ & $\begin{array}{l}0 \\
0 \\
0\end{array}$ & 0 & $85.8 \%$ & $\begin{array}{l}0 \\
0 \\
+\end{array}$ & $34 \%$ & $73.8 \%$ & No \\
\hline 4 & $\begin{array}{l}\text { Syn. } \\
\text { Phae. } \\
\text { Dun. }\end{array}$ & $\begin{array}{l}+ \\
+ \\
+\end{array}$ & $\begin{array}{l}0 \\
+ \\
0\end{array}$ & $\begin{array}{l}0 \\
+ \\
0\end{array}$ & + & $28 \%$ & $\begin{array}{l}- \\
0 \\
+\end{array}$ & $46.6 \%$ & $32.7 \%$ & Yes \\
\hline 5 & $\begin{array}{l}\text { Syn. } \\
\text { Phae. } \\
\text { Dun. }\end{array}$ & $\begin{array}{l}+ \\
- \\
0\end{array}$ & $\begin{array}{l}+ \\
0 \\
-\end{array}$ & $\begin{array}{l}0 \\
0 \\
0\end{array}$ & 0 & $60.6 \%$ & $\begin{array}{l}0 \\
- \\
+\end{array}$ & $49.6 \%$ & $58 \%$ & No \\
\hline 6 & $\begin{array}{l}\text { Syn. } \\
\text { Phae. } \\
\text { Dun. }\end{array}$ & $\begin{array}{l}+ \\
+ \\
0\end{array}$ & $\begin{array}{l}0 \\
0 \\
0\end{array}$ & $\begin{array}{l}0 \\
0 \\
0\end{array}$ & 0 & $41.2 \%$ & $\begin{array}{l}0 \\
- \\
+\end{array}$ & $49.3 \%$ & $43.1 \%$ & Yes \\
\hline 7 & $\begin{array}{l}\text { Syn. } \\
\text { Phae. } \\
\text { Dun. }\end{array}$ & $\begin{array}{l}0 \\
0 \\
0\end{array}$ & $\begin{array}{l}0 \\
- \\
-\end{array}$ & $\begin{array}{l}- \\
-\end{array}$ & 0 & $87.5 \%$ & $\begin{array}{l}- \\
0 \\
+\end{array}$ & $33.3 \%$ & $82.7 \%$ & No \\
\hline 8 & $\begin{array}{l}\text { Syn. } \\
\text { Phae. } \\
\text { Dun. }\end{array}$ & $\begin{array}{l}0 \\
0 \\
+\end{array}$ & $\begin{array}{l}0 \\
+ \\
+\end{array}$ & $\begin{array}{l}- \\
0 \\
+\end{array}$ & - & $57.2 \%$ & $\begin{array}{l}- \\
0 \\
+\end{array}$ & $47.3 \%$ & $54.9 \%$ & Yes \\
\hline 9 & $\begin{array}{l}\text { Syn. } \\
\text { Phae. } \\
\text { Dun. }\end{array}$ & $\begin{array}{l}+ \\
- \\
+\end{array}$ & $\begin{array}{l}0 \\
- \\
+\end{array}$ & $\begin{array}{l}- \\
+ \\
+\end{array}$ & - & $66.2 \%$ & $\begin{array}{l}0 \\
0 \\
-\end{array}$ & $55.3 \%$ & $63.7 \%$ & No \\
\hline 10 & $\begin{array}{l}\text { Syn. } \\
\text { Phae. } \\
\text { Dun. }\end{array}$ & $\begin{array}{l}0 \\
0 \\
+\end{array}$ & $\begin{array}{l}- \\
- \\
+\end{array}$ & $\begin{array}{l}- \\
- \\
+\end{array}$ & - & $68 \%$ & $\begin{array}{l}- \\
0 \\
0\end{array}$ & $64 \%$ & $67.3 \%$ & No \\
\hline
\end{tabular}

\section{Effect of freezing}

Rapid freezing (Protocol 1). Rapid freezing induced a cell loss and a FALS and WALS decrease except for Phaedactylum tricornutum. Rapid freezing preserved the FALS and the CHL intensities, except for cyanobacteria CHL and PHY fluorescence. It should not be used for Dunaliella sp. WALS, as cell losses are significant (minimum variation $54 \%$ for Dunaliella sp.). The total variation of all the parameters was $58.9 \%$, so this protocol should not be used to preserve a natural sample.

Slow freezing (Protocol 3). Slow freezing did not induce any noticeable cell loss, particularly for cyanobacteria. The variation obtained for Dunaliella sp. FALS was quite negligible $(7 \%)$, but this protocol led to dramatic changes in Phaeodactylum tricornutum FALS and WALS and Dunaliella sp. WALS (variation of intensities $85.8 \%$ ). Likewise the change in cell concentration could be accepted for Dunaliella sp. (5\%), but not for Synechocystis sp. or Phaeodactylum tricornutum (ca $46 \%$ ). The total modification of intensities and cell concentrations reached $73.8 \%$, which was too high to be accepted.

\section{Effect of chemical fixation}

With rapid freezing and chemical fixation, cell loss and fluorescence decreases were more significant than with rapid freezing alone. Light scattering (FALS and WALS) fluctuated but peak intensity remained closer to the initial fresh intensity. Debris populations displayed a large variance curve with weaker parameter intensities. Chemical fixation did not induce any real improvement compared to slow freezing alone.

Rapid freezing plus chemical fixation (Protocol 2). This protocol preserved autofluorescence very well (mean variation $12.5 \%$ ) except for cyanobacteria. This protocol should not be used for cyanobacteria PHY 
fluorescence and Phaeodactylum tricornutum FALS. The variation of the cell concentration ranged between $22 \%$ (Dunaliella sp.) and $43 \%$ (Synechocystis sp.), and if all the parameters were considered, the total variation was $89 \%$. This protocol should not be used

Slow freezing plus chemical fixation (Protocol 4). The results for PHY, FALS and the intensities of the diatoms were very promising (variation ca $8 \%$ ); moreover all intensity variation rates exceeded the limit of $80 \%$. Therefore, this protocol could be used (mean intensity variation $28 \%$, except for Dunaliella sp., which showed a cell loss of only $5 \%$. The cell concentration variations were very significant, as high as $95 \%$ for Synechocystis sp.

\section{Effect of cryoprotectants}

Cryoprotectant addition reduced cell loss but pigment fluorescence intensities generally decreased. The Student's $t$-test results showed DMSO addition to be the best method for Phaeodactylum tricornutum WALS preservation. Whenever followed by chemical fixation, DMSO protected cyanobacteria PHY and Dunaliella sp. FALS. Glycerol addition preserved Dunaliella sp. CHL. Cryoprotectant mixture plus chemical fixation preserved Dunaliella sp. FALS. Generally, an increase of the population variance was noticeable with the addition of 1 or 2 cryoprotectants resulting in a subsequent increase of the arithmetic mean.

Slow freezing plus DMSO (Protocol 5). The preservation of Synechocystis sp. FALS, WALS and cell concentration seemed to be suitable $(11,13$ and $26 \%$ respectively), but the variation exceeded $80 \%$ for Phaeodactylum tricornutum FALS and cell concentration, and Dunaliella sp. WALS. Total variation remained at $58 \%$ which was only of borderline acceptability.

Slow freezing plus glycerol (Protocol 6). This protocol showed little variation for Phaeodactylum tricornutum FALS (13\%), and Dunaliella sp. cell concentration, but was not suited for $P$. tricornutum cell concentration. Total variation equaled $43 \%$. This was the most effective protocol used among the cryoprotectants.

Slow freezing plus cryoprotectant mixture (Protocol 7). This protocol should be avoided for Phaeodactylum tricornutum and Dunaliella sp. WALS, and Synechocystis sp. and Dunaliella sp. CHL. Moreover, the cell loss was too significant for Synechocystis sp. whereas the result for cell concentration seemed promising for Dunaliella sp. (5\%). Therefore this protocol cannot be recommended because of the total variation of $82.7 \%$.

Slow freezing plus DMSO and chemical fixation (Protocol 8). This protocol gave very good results for all Dunaliella sp. parameters and Phaeodactylum tricornutum WALS (mean variation $12 \%$ ). In contrast, the variations obtained for the cyanobacteria PHY autofluorescence exceeded the limit of $80 \%$. Total variation was $54.9 \%$

Slow freezing plus glycerol and chemical fixation (Protocol 9). This protocol preserved Dunaliella sp. intensities and Phaeodactylum tricornutum fluorescence peak but could not be used to analyze Synechocystis sp., P. tricornutum FALS, Dunaliella sp. cell concentration, or a natural sample. Total variation obtained with this protocol equaled $63.7 \%$.

Slow freezing plus cryoprotectant mixture and chemical fixation (Protocol 10). This protocol preserved Phaeodactylum tricornutum fluorescence and Dunaliella sp. parameters, but should not be used for Synechocystis sp. fluorescence, $P$. tricornutum FALS or WALS, or cell concentrations (minimum variation $35 \%$ for $P$. tricornutum).

After storage of $1 \mathrm{mo}$, the best protocol seemed to be slow freezing alone, with chemical fixation to preserve Phaeodactylum tricornutum FALS and WALS respectively, slow freezing with chemical fixation and glycerol addition for Dunaliella sp. FALS and CHL and $P$. tricornutum $\mathrm{CHL}$, and slow freezing with the cryoprotectant mixture for Dunaliella sp. WALS (see Fig. 2A, B for FALS, Fig. 2C, D for CHL results).

After storage for $1 \mathrm{wk}$, Protocol 4 appeared to be best for FALS and PHY preservation in particular but it might have affected cell concentration, particularly for Synechocystis sp. (Fig. 2). For WALS and CHL, it was more difficult to select one specific protocol.

Results showed a large variety of responses. Some intrinsic variations might be explained by insufficient homogeneity of the sample, differential positioning of non-spherical cells, and possibly medium viscosity.

Several results could have led to misleading interpretations. For example, unfrozen Synechocystis sp. strain analysis with glycerol addition showed 2 peaks of WALS. Curve area seemed to be equal to that observed without glycerol addition, so that glycerol filtration or contamination could not be the cause. This could be explained by a weaker scattering intensity of peripheral cells swept along by sheath as compared to the cells located in the centre of the glycerol fluid. Analysis of samples with microspheres and the different compounds have been investigated. Intensity of light scattering remained constant in all experimental solutions indicating that the scattering seen with the cells was actually due to cellular responses, and not merely to changes in the optical properties of the solutions, except with Protocol 7 which led to a weaker intensity of FALS and WALS. Likewise, CHL increase could be seen for Dunaliella sp. with Protocol 3. This 

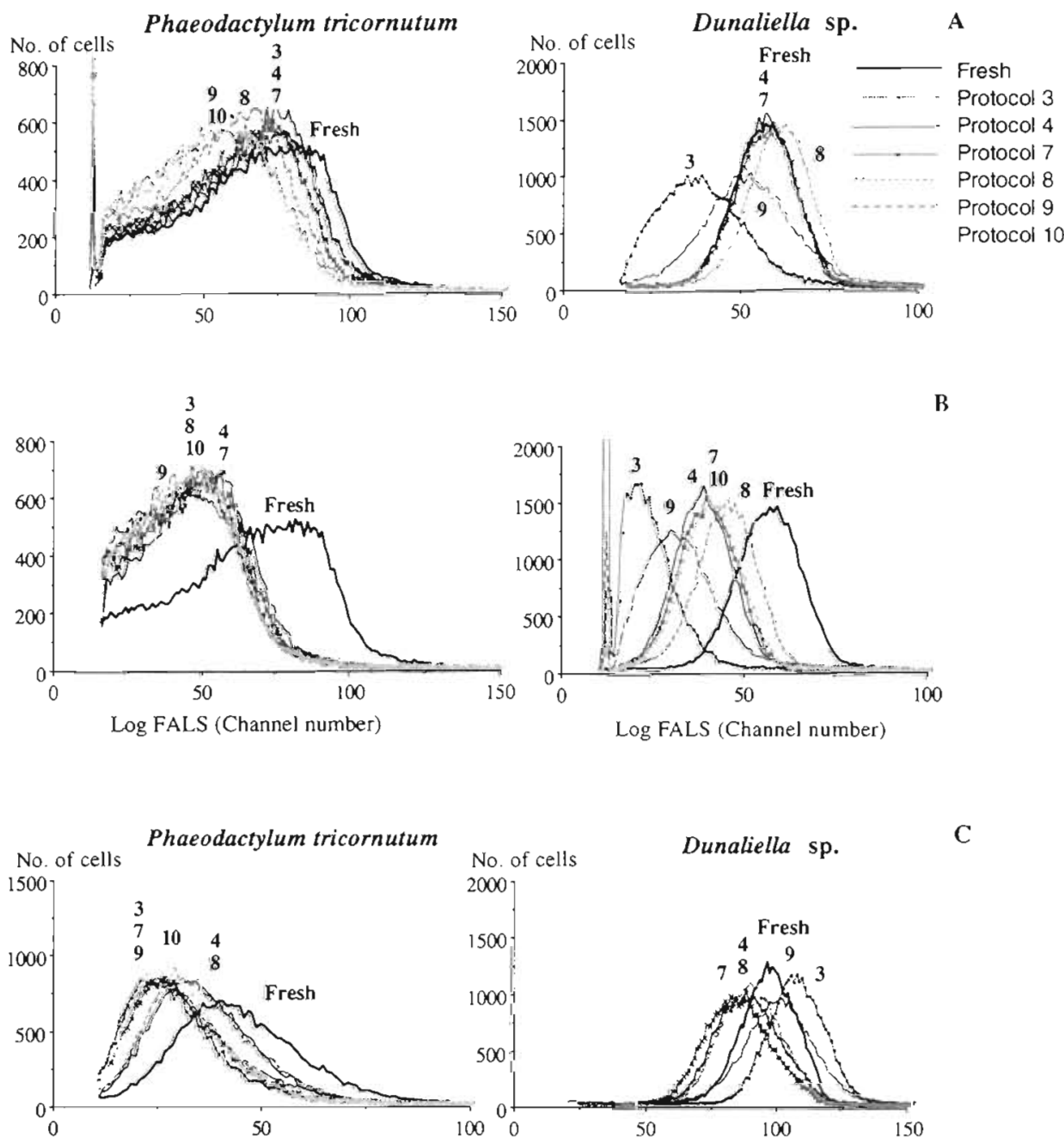

Fig. 2. Variation of the forward angle light scattering (FALS) (A, B) and chlorophyll fluorescence (CHL) (C, D) of Phaeodactylum tricornutum and Dunaliella sp. with Protocols $3,4,7,8,9$ and 10 after 1 wk $(A, C)$ and 1 mo $(B, D)$ storage

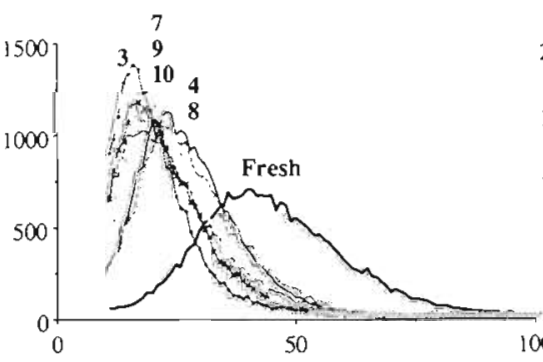

Log CHL (Channel number)

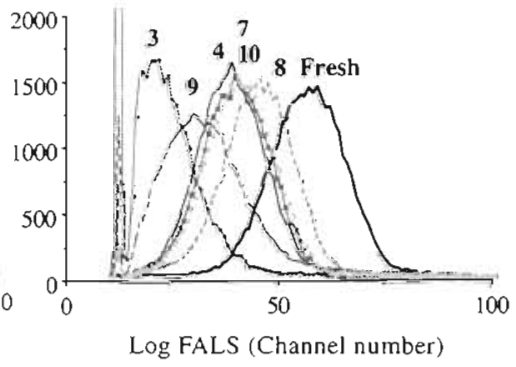

B

C

D

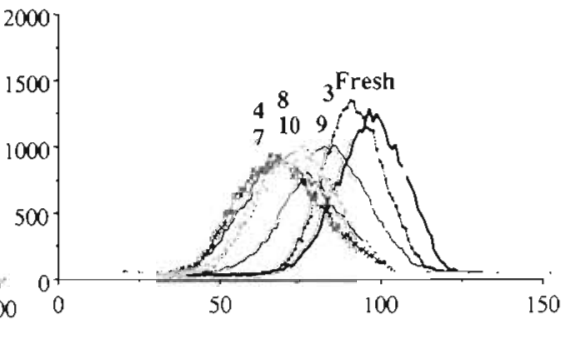

$\log$ CHL (Channel number) might be explained by the decrease of cellular volume which corresponds with an increase of pigment concentration per cell and a subsequent higher fluorescence-like intensity, or by a decoupling between chlorophyll and photosynthesis inducing an increase of observed fluorescence. DMSO was examined because its well-known property of cell permeation makes it more effective than glycerol in penetrating the cell's interior. Glycerol is a non-penetrating compound with respect to the particular cells under study. As a matter of fact, there is a distinction between penetrating and non-penetrating mechanisms. Penetrating compounds such as DMSO, and glycerol to some extent, affect the characteristics of the cytosol, particularly in not allowing an excessive exodus of water from the cells too early in the freezing process. Non-penetrating compounds such as glycerol can, according to the species, exert dehydrative effects on the cell, along with their 
colligative effect of dilution surrounding the cell. So the results depend on the nature of the cryoprotectants and on the biophysical properties of wall and cell membrane, cell health and stresses.

In this study, the negative results observed with Synechocystis sp. compared to the other strains could be explained by its growth state, which is in fact closer to its natural conditions. In the same way, the effects of the different rates of freezing will be dependent on the biophysical properties of cell walls and membranes and on the cell surface/volume ratio. But the different mechanisms are not still completely understood and will require further studies.

\section{CONCLUSION}

Cryoprotective methods did not preserve intensities but rather prevented cell damage. They can be recommended for quantitative cell studies. However Student's $t$-tests did not take into account cell losses. Therefore, even if results of chemical fixation seem promising according to these tests, they do not reflect the reality of the situation. Particularly for strains like Synechocystis sp., a good preservation of intensity did not coincide with a good preservation of the whole population. This could be very important when an analysis of cell concentration in the natural environment is required. However, some progress was achieved. We are now able to choose a protocol to measure one or several parameters using the percentage lost in comparison to the fresh sample.

Generally, both chemical fixation with slow freezing and glycerol addition without chemical fixation were the best methods for all studied parameters.

For small cell concentrations, Protocol 8 can be recommended and Protocols 1 and 4 were able to provide useful information about cell size. CHL fluorescence intensity of algal cells was preserved by Protocols 1, 2 and 9, and the PHY fluorescence of cyanobacteria by Protocol 4. So, in a mixed species population, the best (but not always realistic) solution should be to preserve aliquots of the whole sample with 3 different methods:

- Protocol 1 to analyse algal cell population fluorescence and size,

- Protocol 4 for cyanobacteria population PHY fluorescence and size,

- Protocol 8 for cell concentrations although a loss of large cells occurs

The use of cryoprotectants appeared promising for other studies of fluorescence induced by fluorochromes such as DAPI, which normally requires a preliminary cell permeabilization. Other cryoprotectants such as polymeric compounds - sucrose, polyethylenglycol (PEG), hydroxyethyl starch (HES), for example might be investigated. In any case, it will always be difficult to preserve the particles of the whole sample population for all fluorescent studied parameters.

Acknowledgements. We acknowledge the financial support of the Land-Sea Interactions Coordinated Group from C.N.R.S., the Ministry of Education, and the Commission of European Communities 4th Research and Development Programme under contract EV4V-0111-F. We are indebted to Daniel Vaulot for reviewing this text.

\section{LITERATURE CITED}

Alanen, K. A., Klemi, P. J., Joensuu, H., Kujary, H., Pekkala, E. (1989a). Comparison of fresh, ethanol-preserved and paraffin-embedded samples in DNA flow cytometry. Cytometry 10: 81-85

Alanen, K. A., Klemi, P. J., Taimela, S., Joensuu, H. (1989b). A simple method for flow cytometry DNA analysis. Cytometry 10: 86-89

Berkaloff, C. (1976). Evolution de l'ultrastructure de la pigmentation et de l'activité de l'algue verte Protosiphon botryoides (Kùtz) kleps en culture. Thèse de Doctorat d'état ès Sciences Naturelles de Paris VI

Brun-Cottan, J. C. (1986). Vertical transport of particles within the acean. In: The role of air-sea exchange in geochemical cycling. D. Reidel Publ., Dordrecht, p. 83-111

Burkill, P. H. (1987). Analytical flow cytometry and its application to marine microbial ecology. In: Sleigh, M. A (ed.) Microbes in the sea. Ellis Horwood Ltd, Chichester, p. $139-166$

Cucci, T. L., Shumway, S. E., Brown, W. S., Newell, C. R. (1989). Using phytoplankton and flow cytometry to analyse grazing by marine organisms. Cytometry 10: 659-669

Finkle, B. J., Zavala, M. E., Ulrich, J. M. (1985). Cryoprotective compounds in the viable freezing of plant tissues. In: Kartha, K. K. (ed.) Cryoprotection of plant cells and organs. CRC Press, Boca Raton, p. 75-113

Guillard, R. R. L., Ryther, J. H. (1962). Studies of marine diatoms. I. Cyclotella nana Hustedt and Detonula confervacea (cleve) Gran. Can. J. Microbiol. 8: 229-23

Li, W. K. W. (1989). Shipboard analytical flow cytometry of oceanic ultraphytoplankton. Cytometry 10: $564-579$

Martin, J. M., Moreira-Turcq, P. (1991). A new methodology for the characterization of organic coatings on aquatic particles. Mar. Pollut. Bull. 6: 287-290

McGann, L. E., Walterson, M. C., Hogg, L. M. (1988). Light scattering and cell volumes in osmotically stressed and frozen-thawed cells. Cytometry 9: 33-38

Morris, G. J. (1987). Direct chilling injury. In: Grant, B. W. W., Morris, G. J. (eds.) The effects of low temperatures on biological systems. E. Arnold Ltd, London, p. 120-146

Olson, R. J., Vaulot, D., Chisholm, S. W. (1985) Marine phytoplankton distributions measured using shipboard flow cytometry. Deep Sea Res. 32: 1273-1280

Premazzi, G., Buanoccorsi, G., Zilio, P. (1989). Flow cytometry in algal studies. Wat. Res. 23: 431-442

Rippka, R., Deruelles, J., Waterbury, J. B., Herdman, M., Stanier, R. Y. (1979). Generic assignments strains histories and properties of pure cultures of cyanobacteria. J. gen. Microbiol. 111: 1-61 
Schmidt, I., Schmidt, P., Giorgi, J. V. (1988). Conversion of logarithmic channel numbers into relative linear fluorescence. Cytometry 9: 533-538

Vaulot, D., Courties, C., Partensky, F. (1989). A simple method to preserve oceanic phytoplankton for flow cytometry analysis. Cytometry 10:629-635

Vaulot, D., Ning, X. (1988). Abundance and cellular characteristics of marine Synechocystis spp. in the dilution zone of the Changjiang (Yangtze River, China). Cont. Shelf Res. 8: $1171-1186$

This article was submitted to the editor
Withers, L. A. (1985). Cryopreservation of cultured plant cells and protoplasts. In: Kartha, K. K. (ed.) Cryoprotection of plant cells and organs. CRC Press, Boca Raton, p. $243-265$

Yentsch, C. M., Horan, P. K., Muirhead, K., Dortch, Q. Haugen, E., Legendre, L., Murphy, L. S., Perry, M. J., Phinney, D. A., Pomponi, S. A., Spinrad, R. W., Wood, M., Yentsch, C. S., Zahuranec, B. J. (1983). Flow cytometry and cell sorting: a technique for analysis and sorting of aquatic particles. Limnol. Oceanogr. 28: 1275-1280

Manuscript first received: October 21, 1991

Revised version accepted: December 22, 1992 